\title{
Sacred Landscapes
}

\section{Roland BoeR}

UNIVERSITY OF NEWCASTLE

Lyn McCredden

Luminous Moments: The Contemporary Sacred

ATF Press, Adelaide, 2010

ISBN 9781921511950

RRP $\$ 34.00$

For some time now, Lyn McCredden has been one of the leading cultural critics in Australia emphasising the crucial role of religion-or the sacred, as she prefers to call it-in the cultural landscape. This book is a welcome addition to her work in this area. It offers a collection of analyses of how the sacred is manifested outside its expected and traditional forms: in poets who are not 'overtly religious, whose poetry adheres to older, transcendental models of signification' (which thereby excludes, thankfully, the likes of Kevin Hart), but who 'have gone along with the poststructural and postmodern loosening of such ties, diving into the various streams of linguistic scepticism'; (76) in musicians whose relation to sacredness is carnal, ambivalent and unexpected; in novelists who either trouble conventional religious categories or 
speak of a scrappy, earthed sacred; and in moments of everyday encounter with the popular.

Before commenting on those various studies, I need to ask what McCredden means by the 'sacred', especially a 'perverse sacred'. She writes, 'The argument of this book is that what is needed now, globally, is a spirit and an approach which apprehend sacredness as alive in multiple ways, beyond ... the power and constrictions of institutional religion'. McCredden is interested in 'the less systematic, often more spontaneous or ephemeral manifestations of the sacred that arise-are created, drawn upon, dreamed up-in popular and artistic cultures'. It is 'in the eye of beholders, and receivers, and unbelievers', becoming the place where 'our deepest fears, dreams, hopes, doubts, longings, joys are brought into relief, either individually or communally'. ( $\mathrm{x}$-xi) I would add that the book also brings out the very carnal, earthy and fleshed nature of the sacred she seeks, laced with a persistent and healthy engagement with Indigenous concerns.

The chapters of the book fall into two types. The first are the more overtly cultural studies pieces, with a quotidian focus, myriad instances and lashings of theory. Here we find the introduction, which is a kind of Certeauean walking the city, the first chapter on popular cultures, which reminds one most of a collage, the work of a bricoleur (such as Walter Benjamin), the second chapter on public responses to the Bali bombing, the fifth chapter on forms of popular memory and mourning, the ninth chapter on ambivalent expressions of home in popular music, including Icehouse, Goanna, Midnight Oil and Yothu Yindi, and the last chapter on the various responses to the Chamberlain case. The second type of chapter zeroes in on a particular author or musician, preferring to analyse specific texts: Les Murray (Chapter 3), Tim Winton (Chapter 4), Peter Carey (Chapter 6), Vincent Buckley and Sam Wagan Watson (Chapter 7), Pam Brown (Chapter 8) and Nick Cave (Chapter 9). Both types of study have their merits, but I found the focused studies more satisfying and stronger. Here McCredden's background as a literature scholar shows through, especially with regard to poetry. Here are the most arresting insights, the most persistent searches, the best writing. Nearly all the chapters are republished essays from other sources and one notices this feature from time to time. Although they reveal different dimensions of the contemporary sacred, outside conventional forms, the placement of the last chapter on Lindy Chamberlain is curious. Would it 
not have been better located after the study of memory, leaving the passionately and politically engaged study of 'It's a Hungry Home', with its finale a discussion of Yothu Yindi's song, 'Treaty', as a strong conclusion? Here the persistent theme of the need to engage with the unfinished business of everyday indigenous sacredness and justice provides a fitting close.

I also wonder at the strong desire to move outside the walls of conventional and traditional forms of religious expression-here largely Christianity. McCredden's gaze and feet move out from the church and onto the street, so I am puzzled at the invocation of Rowan Williams on a number of occasions. (69-72, 140-1, 144) Williams is now the Archbishop of Canterbury, but he was also a forerunner to the increasingly conservative 'Radical Orthodoxy' movement (he was a teacher of the cranky John Milbank, who now claims the mantle of radical orthodox prophet). So Williams sits strangely as a source of theological insight into the sacred. And the book itself is published by ATF Press, one of the imprint names for the publishing arm of the Australasian Theological Forum. A quick look at the forum's website (http://www.atf.org.au) reveals a very confessional, ecumenical organisation, with its street address listed as the Adelaide College of Divinity. I seek not to uncover some residual basis in the church despite McCredden's desire to step outside, but to suggest that the unexpected, popular, ambivalent forms of sacredness McCredden pursues may happen as much in the intersections between traditional and contemporary, between received forms and their creative new expressions. Or rather, the nature of McCredden's book and the realities of publishing suggest this is the case.

But let us move on to the book's strengths, one of which is the way McCredden highlights the ambivalence of contemporary expressions of the sacred. It may be a 'mongrel ritual' in response to the Bali bombings, in which people express in their rituals a suspicious ambivalence and a desire for participation, yearning for ritual as a mode of dealing with trauma. It may be the close analysis of Les Murray, working deftly between scepticism and admiration, seeking the moments when Murray moves beyond his cranky preaching to let himself go-especially in his numinous, near Pentecostal poem 'The Mouthless Image of God in the Hunter-Colo Mountains'. It may be the edge of language or, rather, the moment before language and religion for which Peter Carey struggles through the very words he seeks to transcend. It 
may be the incarnate, 'sensible transcendent' (Irigaray's phrase) of the urban sacredness uncovered in the poetry of Vincent Buckley and Sam Wagan Watson. It may be the sensual, erotic and carnal sacred of the troubling lyrics of Nick Cave. And it may be the effort to heal the cultural wound of Aboriginal presence that runs throughout the book, showing up sharply in the studies of Pam Brown, Peter Carey and popular music's negotiations of home.

Inevitably, a reader of such a collection ends up locating a few favourite studies. For me, two of these are the studies of Pam Brown and Nick Cave. At the opening to the Brown chapter appears a paragraph that captures the variety and appeal of Brown's poetry. I quote it in full and let it speak for itself, since McCredden has here risen to another level:

There are many ways to peel an onion: sharp knife and tears; under water like your mother taught you; surreptitiously, creeping in, layer by layer; or with sunglasses on. And cunning poet Pam Brown knows them all. There they are, those devastatingly onion-like little poems, with furled skins and layers, offering up biting street-scapes and cafés, half-remembered faraway places, distant friends, rock \& roll, and lost, ordinary cities; that deceptive, seemingly autobiographical voice cruising between wit, boredom, disillusion, nostalgia, paranoia, irony. Always irony. Always the slippery poetics of knowledge warping, even as the poet obsessively scans the texts for narrative: a seeking of 'untranscended/life itself'. (89)

My other favourite is the study of Nick Cave, despite its tendency to focus on the lyrics (as do so many treatments of music by literary and cultural critics). McCredden offers a survey of sacred and theological themes throughout Cave's prodigious writings, including the film, The Proposition. He refuses, she argues, to separate sacred and profane, for they suffuse all of life-flesh, erotics and violence. In the process, he produces an 'idiosyncratic but also embracingly contemporary theology of the fleshed or carnal sacred'. (106) But he is also a seeker of 'divine comfort', for a redemption no matter how uncertain it may be. (107) Here McCredden allows a subterranean theme that runs throughout the book to emerge: a search for redemption, albeit in unexpected ways. How does redemption play out in light of colonial history and Aboriginal oppression? How do people seek balm in the face of tragedy and pain? Without offering conventional answers, McCredden's 
explorations of the manifestations of the contemporary sacred is also a search for redemption.

Roland Boer researches at the University of Newcastle, in the areas of Marxism, religion and culture. Among numerous works his most recent are Criticism of Earth: On Marx, Engels and Theology (2012) and Nick Cave: Love, Death and Apocalypse (2012). 